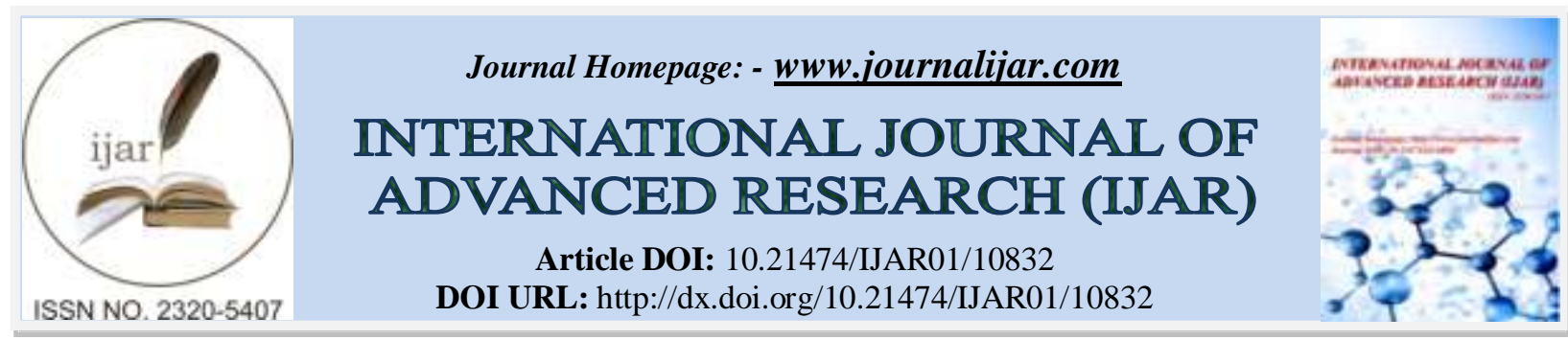

RESEARCH ARTICLE

\title{
GUIDED FNAC OF INTRA-ABDOMINAL AND INTRA-THORACIC MASS LESIONS :EXPERIENCE FROM A TERTIARY CARE HOSPITAL
}

Anu Gupta and Dr. Bharti Devi Thaker

Lecturer, Department of Pathology, Govt. Medical College Jammu.

\section{Manuscript Info}

Manuscript History

Received: 14 February 2020

Final Accepted: 16 March 2020

Published: April 2020

Key words:-

FNAC (Fine Needle Aspiration

Cytology), Intra-Abdominal, Intra-

Thoracic

\begin{abstract}
Introduction: Guided FNAC of Intra-abdominal and Intra-thoracic mass lesions is a cheap, safe and rapid diagnostic modality used in the cytological evaluation of benign as well as malignant deep seated lesions.

Material and Methods: Ours is a retrospective study done in the cytology section of the Department of Pathology Govt. Medical College Jammu over a period of one year from Jan 2019 to Jan 2020. The study included 34 (62.96\%) intra-abdominal and $20(37.04 \%)$ intra-thoracic lesions.

Results: A total of 54 lesions were studied including 34 (62.96\%) intraabdominal and 20 (37.04\%) intra-thoracic. Among intra-abdominal lesions maximum 31 (91.17\%) were US Guided FNAC from hepatobiliary mass lesions followed by 1 (2.94\%) each from ovary, pancreas and retroperitoneum. All the intra-thoracic lesions were CT guided with maximum 16 (80\%) from lungs and 4 (20\%) from mediastinum. Malignant lesions 44 cases $(81.48 \%)$ outnumber the benign lesions 10 cases $(18.51 \%)$.

Conclusion: Image guided FNAC of deep seated lesions can improve the diagnostic yield and a definite diagnosis can be reached in most of the cases.
\end{abstract}

Copy Right, IJAR, 2020,. All rights reserved.

\section{Introduction:-}

Intra-thoracic and Intra-abdominal mass lesions at inaccessible sites pose difficulty in diagnosis. ${ }^{1}$ Image guided FNAC (CT,USG) is an accurate, painless and safe technique in such deep seated lesions for obtaining the tissue for cytological examination and diagnosing neoplastic and inflammatory conditions of both the thorax and abdomen. The most significant advantage of radiological guidance is that while performing the guided FNAC, one can visualize simultaneously whether the needle is within the target lesion or not and also within the target, is it from a solid well represented area or from a necrotic, cystic area which will not guide much to the cytologist in making an exact diagnosis. The added advantage is that it also provides an opportunity for a mutual interaction between the pathologist and the radiologist for the benefit of the patient. ${ }^{2}$ The purpose of the present study is to know the pathological spectrum of intra-abdominal and intra-thoracic mass lesions, to evaluate the possible etiology and to correlate with radiological findings. The high sensitivity and specificity of this widely accepted diagnostic method with minimal complications prompted us to conduct this study.

Corresponding Author:- Dr. Bharti Devi Thaker

Address:- Lecturer, Department of Pathology, Govt. Medical College Jammu. 


\section{Material and Methods:-}

54 patients presenting with intra-abdominal and intra-thoracic mass lesions were included in the study done in the Cytology section of the Department of Pathology Govt. Medical College Jammu over a period of one year from Jan 2019 to Jan 2020. The aspirates were obtained from various anatomic sites such as liver, gallbladder, lungs, pancreas ,ovary, mediastinum, retroperitoneum. Hilar and Paratracheal lymph nodes were also aspirated. The FNAC diagnosis was correlated with clinical and radiological information and final diagnosis was made on the Maygrunwald Giemsa and Pap stained cytological smears. In some cases where Tuberculosis was suspected Ziehl Neelson stain for Acid Fast Bacilli was also done. The lesions were divided into inflammatory, benign and malignant categories. Acellular and inconclusive smears were excluded from the study.

\section{Results:-}

Out of 54 Image guided FNAC's done there were 30 males and 24 females with a M:F ratio of 1.25:1. Maximum patients were above 50 years of age group with the youngest patient of 26 years old male presenting with liver mass and raised alpha fetoprotein of $>1210 \mathrm{ng} / \mathrm{ml}$. US guided FNAC showed sheets, trabeculae and individually scattered cells with round nuclei prominent nucleoli. Some of the cells show bile pigment. Few capillaries transgressing the tumor cells also seen and based on the cytomorphological features a diagnosis of Moderately Differentiated HCC was given. Oldest patient was 70 years old presenting with a large retroperitoneal mass. CT Guided FNAC showed cytomorphological features of a Pleomorphic sarcoma. The number of intra-abdominal and intra-thoracic lesions were $34(62.96 \%)$ and $20(37.04 \%)$ respectively Table 1 . Site wise distribution is given in Table 2. Cytological distribution of intra-abdominal and intra-thoracic lesions is given in Table 3 and Table 4.

Table No.1:- Distribution of Guided FNAC.

\begin{tabular}{|c|c|c|}
\hline Site & No. & Percentage (\%) \\
\hline Intra-abdominal & 34 & 62.96 \\
\hline Intra-thoracic & 20 & 37.04 \\
\hline Total & 54 & 100 \\
\hline
\end{tabular}

Table No.2:- Site-wise distribution of cases.

\section{Site-wise distribution of cases}

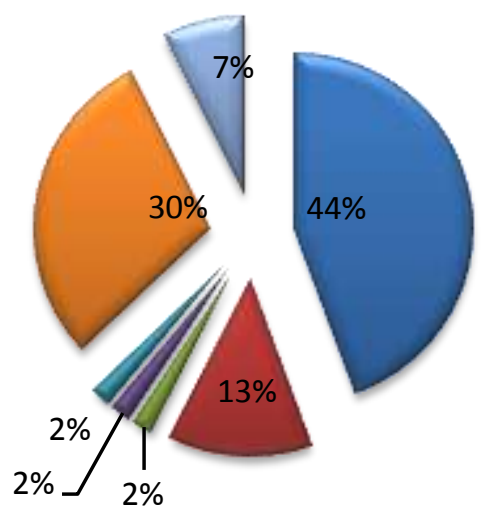

Liver

Gall Bladder

Pancreas

Ovary

Retroperitoneum

Lung

Mediastinum

Table No. 3:- Cytological Diagnosis of Intra-abdominal Lesions.

\begin{tabular}{|c|c|c|c|}
\hline Site & Lesions & Cases & Percentage (\%) \\
\hline \multirow{3}{*}{$\begin{array}{c}\text { Liver } \\
(\mathrm{n}=24)\end{array}$} & $\begin{array}{c}\text { Metastatic deposits of } \\
\text { Adenocarcinoma }\end{array}$ & 12 & 35.29 \\
\cline { 2 - 4 } & $\begin{array}{c}\text { Poorly Differentiated } \\
\text { Carcinoma }\end{array}$ & 02 & 5.88 \\
\cline { 2 - 4 } & Cholangiocarcinoma & 01 & 2.94 \\
\cline { 2 - 4 } & Hepato Cellular & 06 & 17.64 \\
\hline
\end{tabular}




\begin{tabular}{|c|c|c|c|}
\hline \multirow{2}{*}{} & Carcinoma & & \\
\cline { 2 - 4 } & Hydatid Cyst & 01 & 2.94 \\
\cline { 2 - 4 } & Abscess & 02 & 5.88 \\
\hline \multirow{2}{*}{ Gall Bladder } & Adenocarcinoma & 06 & 17.64 \\
\cline { 2 - 4 } & $\begin{array}{c}\text { Squamous Cell } \\
\text { Carcinoma }\end{array}$ & 01 & 2.94 \\
\hline Pancreas & Adenocarcinoma & 01 & 2.94 \\
\hline Ovary & $\begin{array}{c}\text { Mucinous Cyst } \\
\text { Adenocarcinoma }\end{array}$ & 01 & 2.94 \\
\hline Retroperitoneum & Pleomorphic Sarcoma & 01 & 2.94 \\
\hline \multicolumn{2}{c}{ Total } & 34 & 100 \\
\hline
\end{tabular}

Table No.4:- Cytological Diagnosis of Intra-thoracic Lesions.

\begin{tabular}{|c|c|c|c|}
\hline Site & Lesions & Cases & Percentage (\%) \\
\hline \multirow{4}{*}{$\begin{array}{c}\text { Lung } \\
(\mathrm{n}=16)\end{array}$} & $\begin{array}{c}\text { Squamous Cell } \\
\text { Carcinoma }\end{array}$ & 07 & 35 \\
\cline { 2 - 4 } & Adenocarcinoma & 03 & 15 \\
\cline { 2 - 4 } & Small Cell Carcinoma & 02 & 10 \\
\cline { 2 - 4 } & $\begin{array}{c}\text { Granulomatous } \\
\text { (Tuberculosis) }\end{array}$ & 04 & 20 \\
\hline \multirow{4}{*}{$\begin{array}{c}\text { Mediastinum } \\
(\mathrm{n}=4)\end{array}$} & Teratoma & 02 & 10 \\
\cline { 2 - 4 } & Thymoma & 01 & 05 \\
\cline { 2 - 4 } & $\begin{array}{c}\text { Non Hodgkins } \\
\text { Lymphoma }\end{array}$ & 01 & 100 \\
\hline \multicolumn{2}{|c|}{} & 20 & 05 \\
\hline
\end{tabular}

\section{Discussion:-}

In the era of evidence based treatment, guided FNAC's provide the optimum benefit to the patient in reaching a correct diagnosis and being a safe, simple and minimally invasive procedure has facilitated easy collection of cellular material with greater accuracy. ${ }^{3}$ Many studies on Image guided FNAC from various sites by most of the authors reported fairly good sensitivity, specificity and diagnostic accuracy. ${ }^{2}$ Procedure being jointly done by a pathologist and radiologist allows immediate assessment by on site cytopathologist, thus improving the adequacy of the technique. ${ }^{4}$ Liver 24 cases and Lung 16 cases were the most common sites for Image Guided FNAC in our study which is comparable to the study by Sheikh et $\mathrm{al}^{5}$ and Adhikari RC. ${ }^{6}$ The age range of the patient in our study was 26-70 years. Tan $\mathrm{KB}$ et $\mathrm{al}^{7}$ in his study found age range of 11-82 years. Among intra-abdominal cases, hepatobiliary lesions 31 cases were the most common in the present study with the maximum cases encountered as metastatic deposits of Adenocarcinoma in liver 12 cases followed by 6 cases each of Hepatocellular carcinoma and Adenocarcinoma of the Gall bladder. This was similar to the study of Adhikari $\mathrm{RC}^{6}$ and Parijuli $\mathrm{S}^{3}$ who in their study also found Metastatic deposits of Adenocarcinoma in liver to be the most common finding. Zarger et al ${ }^{8}$ however found the most common malignancy as carcinoma Gallbladder followed by Hepatocellular carcinoma. There was 1 case of Pancreatic lesion in our study. Sheikh et al however found 6 pancreatic lesions amongst the 120 cases. Present study found 1 case each of Mucinous Cystadenocarcinoma Ovary and Retroperitoneal Pleomorphic sarcoma.

A review of Thoracic FNA by a study conducted by Stewart $\mathrm{CJ}^{9}$ revealed a specificity of $100 \%$ in cases of malignancies. Amongst CT guided intra-thoracic mass lesions, Lung lesions were maximum $16(80 \%)$ with maximum 7 cases of Squamous cell carcinoma followed by 3 cases of Adenocarcinoma and 2 cases of Small cell carcinoma, similar to the study done by Anupam saha. ${ }^{10}$ All the 4 benign non neoplastic lesions in Lung were diagnosed as granulomatous inflammation with AFB positive consistent with Tuberculosis. Jain et $\mathrm{al}^{11}$ described that the most common mediastinal lesions were Lymphoma, Thymoma, Germ cell tumor, Neuroendocrine tumors and inflammatory lesions, besides metastatic lesions. In our study Mature cystic Teratoma was commonest 2 cases followed by 1 case each of Thymoma and Non Hodgkin's Lymphoma. Thymoma was seen in a 54 years old male presenting with anterior mediastinal mass, cytomorphology showed cohesive tissue fragments of oval to spindle cells admixed with lymphoid cell. A single case of NHL (Non Hodgkins Lymphoma) was seen in a 30 years old 
male with anterior mediastinal mass. Cytomorphological features showed atypical lymphoid cells with prominent nucleoli and irregular nuclear margins.

CT guided FNAC of intra-thoracic lesions is a low cost and accurate diagnostic procedure to avoid major surgical procedures like thoracotomy. ${ }^{12}$ Barrios et $\mathrm{al}^{13}$ and Stewart $\mathrm{CJ}^{9}$ recommended that image guided FNAC should be used as routine procedure in the study of abdominal lesions and Pulmonary lesions.

\section{Microphotograph showing Poorly differentiated carcinoma.}

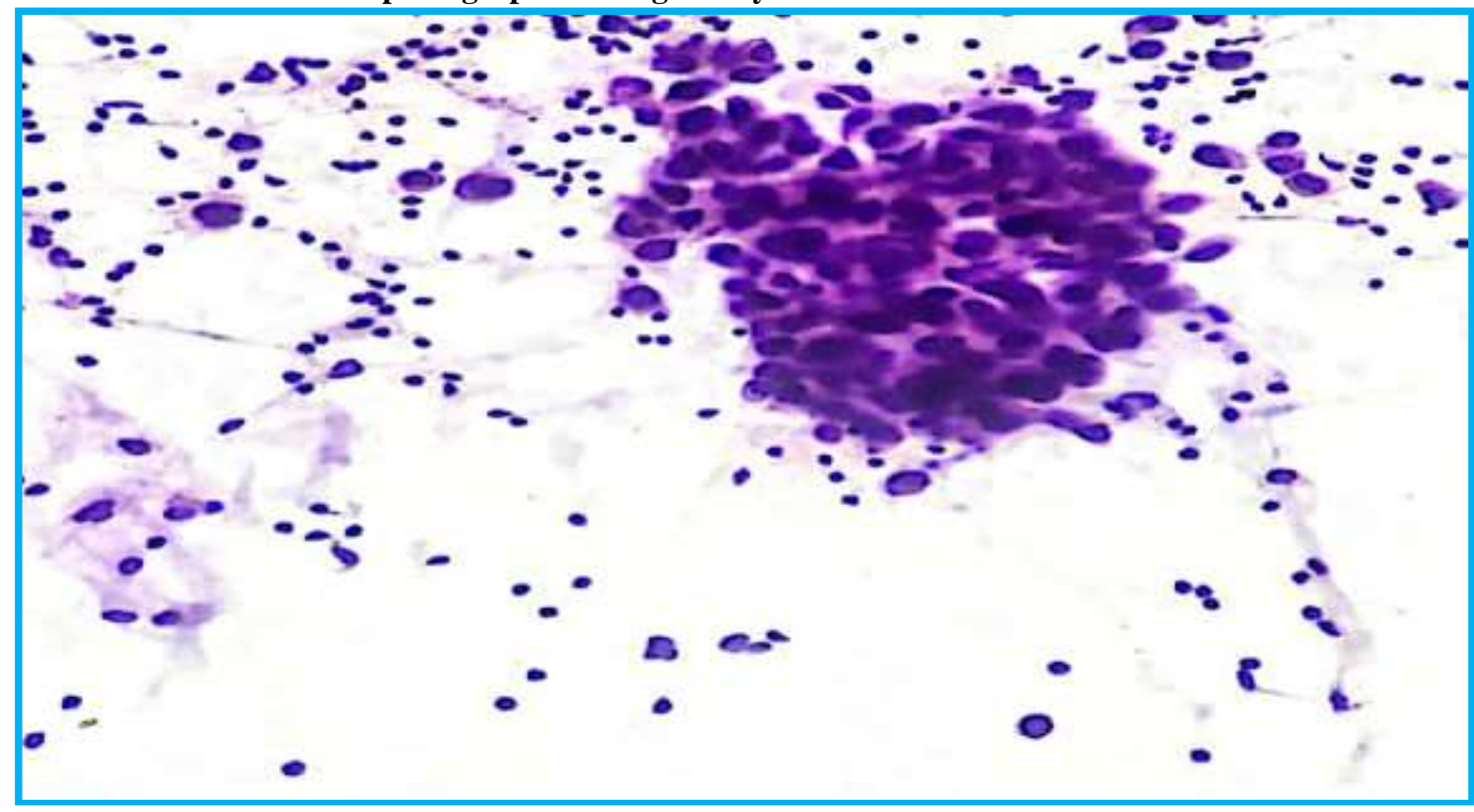

Microphotograph showing Thymoma.

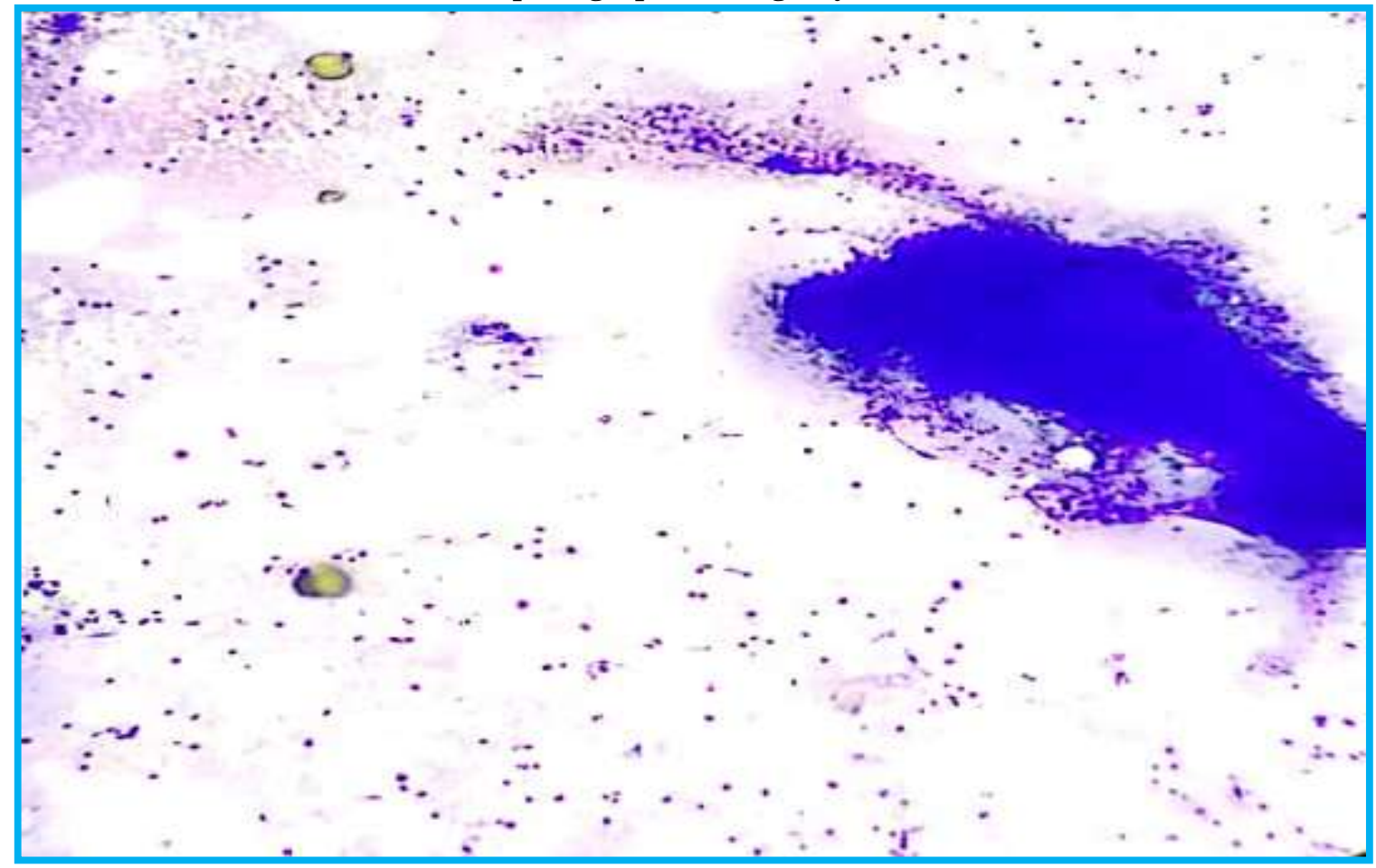




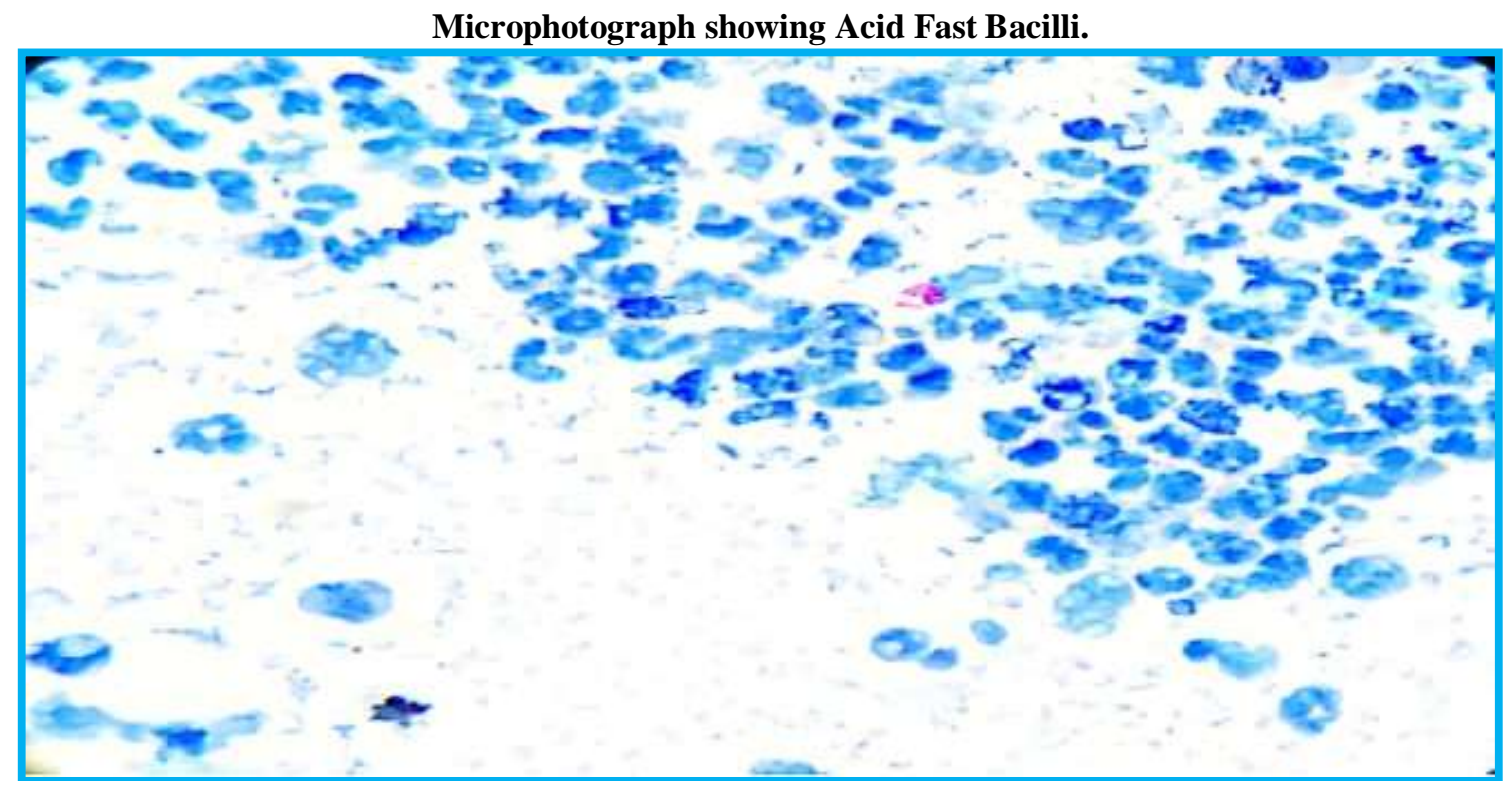

\section{Conclusion:-}

Image Guided FNAC of deep seated lesions benefit the patient's using simple technique and this outpatient procedure with the lowest cost to the patient avoids lengthy hospital stay in case of surgical biopsies.

\section{References:-}

1. Chowdhary M, Gupta R, Singh K. Role of image guided fine needle aspiration cytology in the diagnosis of intra-abdominal and intra-thoracic lesions. Int J Res Med Sci 2019; 7: 1584-8.

2. Pujani M, Jetley S, Jairajpuri Z S, Khan S, Hassan M J, Rana S et al. A Critical Appraisal of the Spectrum of Image Guided Fine Needle Aspiration Cytology: A Three Year Experience from a Tertiary Care Centre in Delhi. Turkish Journal of Pathology 2016; 32: 27-34.

3. Parajuli S, Tuladhar A, Basnet R B. Ultrasound and computed tomography guided fine needle aspiration cytology in diagnosing intra-abdominal and intra thoracic lesions. Journal of Pathology of Nepal 2011; 1: 1721.

4. Stewart CJ, Coldewey J, Stewart IS. Comparison of fine needle aspiration cytology and needle core biopsy in the diagnosis of radiologically detected abdominal lesions. J Clin Pathol 2002; 55: 93-7.

5. Sheikh M, Sawhney S, Dev P, Al-saeed O, Behbehani A. Deepseated thoracic and abdominal masses: usefulness of ultrasound and computed tomography guidance in fine needle aspiration cytology diagnosis. Australas Radiol 2000; 44: 155-60.

6. Adhikari RC, Tuladhar A, Shrestha S, Sharma SK. Deep-seated thoracic and abdominal lesions: usefulness of ultrasound guided fine needle aspiration cytology, a 3 year experience. Nepal Medical Coll J 2010; 12: 20-5.

7. Tan K B, Thamboo T P, Wang S C, Nilsson B, Rajwanshi A, Tellez M S. Audit of Transthoracic Fine Needle Aspiration of the Lung: Cytological Subclassification of Bronchogenic Carcinomas and Diagnosis of Tuberculosis. Singapore Med J 2002; 43 (11): 570-575.

8. Zarger SA, Khuroo MS, Maharjan R, Shah P. Ultrasound guided FNAC of gallbladder masses. Radiology 1991; 179: $275-8$.

9. Stewart C JR, Stewart I S. Immediate assessment of fine needle aspiration cytology of lung. J Clin Pathol 1996; $49 ; 839-843$.

10. Saha A, Kumar K, Choudhari M K. Computed tomography-guided fine needle aspiration cytology of thoracic mass lesions: A study of 57 cases. J Cytol 2009; 26(2): 55-59.

11. Jain M, Singh S, Prasad A, Rao L, Kumar S. Symposium on Mediastinal Lesion. Journal of Cytology: 2006: 23(2): 59-70.

12. Rangaswamy M, Zacharia T T, Vimala M G. Study of computed tomography-guided fine needle aspiration cytology of thoracic lesions. J Cytol 2012; 29 (1): 30-34.

13. Barrios S, Hamana N, Quiros E. Cytology and biopsy by fine needle aspiration with ultrasound guidance in abdominal tumors. G E N. 1989; 43(3): 155-60. 